\title{
LITERATURA BRASILEIRA EM CONTEXTO FRANCÓFONO
}

\section{LITTÉRATURE BRÉSILIENNE DANS UN CONTEXTE FRANCOPHONE}

\section{Ana Crélia Penha Dias ${ }^{1}$}

\section{Apresentação}

Saulo Neiva é doutor e livre-docente pela Universidade de Paris 3-Sorbonne Nouvelle, professor titular de literatura portuguesa e brasileira da Universidaté Clermont Auvergne. Publicou a primeira edição bilingue de Várias histórias / Histoires diverses, de Machado de Assis (Classiques Garnier). Foi curador do projeto Machado de Assis, le Sorcier de Rio, que incluiu uma exposição na sede da Unesco e a realização de um dossiê pedagógico dirigido aos professores do ensino primário francês. Coorganizou, com Alain Montandon, o Dictionnaire raisonné de la caducité des genres littéraires (Droz) e publicou diversos trabalhos sobre epopeia e modernidade. Atualmente, é diretro regional para o Caribe da Agência Universitária da Francofonia (AUF).

Pedro Meira, na introdução da obra $A$ primeira aula, obra que tematiza a experiência de dar aula de Literatura brasileira fora do Brasil, diz que a proposta do livro acabou se expandindo para outras questões, implicadas na prática deste professor: tradução, circulação das obras, força de determinado nicho editorial, formação de leitores. Fale um pouco sobre a experiência do deslocamento de estar fora do país e ao mesmo tempo imerso no universo simbólico cultural por ser professor de Literatura Brasileira em terras estrangeiras.

Ensinar literatura brasileira a um público que não tem nenhuma ou quase nenhuma vivência da cultura brasileira é uma experiência extremamente enriquecedora. Antes de tudo, porque exige que o professor suspenda suas "certezas" e precise explicar "obviedades". Surgem regularmente dificuldades de compreensão linguística. É necessário explicitar alusões e subentendidos que seriam evidentes para outro público. E pessoalmente sempre me interrogo: para que iniciar estudantes numa disciplina tão confidencial? Com que objetivo orientar um doutorando numa área tão árida em termos de inserção profissional? Outro obstáculo, bastante

\footnotetext{
${ }^{1}$ Graduada em Letras pela UFRJ, Especialista em Literatura Infantil e Juvenil, Mestre e Doutora em Letras Vernáculas pela UFRJ. Professora da UFRJ. É membro do Grupo de Pesquisa “A narrativa ficcional para crianças e jovens: teorias e práticas culturais" (UERJ). É líder do GT da ANPOLL Literatura e Ensino. Atua como docente do ProfLetras/UFRJ. E-mail: anacrelia@gmail.com
} 
árduo há alguns anos, foi atenuado recentemente, graças às novas tecnologias: a dificuldade de acesso a obras editadas no Brasil.

\section{Faça um breve panorama da circulação da literatura brasileira na França: como se constitui ali um cânone literário brasileiro?}

O mercado editorial francês foi relativamente pioneiro na tradução de livros brasileiros, em comparação por exemplo com o inglês. Desde então, houve uma progressão constante da quantidade de livros editados, que decolou progressivamente a partir da década de1950. Ao longo desses anos, os países anglófonos traduziram bem menos livros brasileiros do que a França. No entanto, se confrontarmos esses dados com o espaço crescente que a edição francesa concede às literaturas estrangeiras, notaremos que a presença do Brasil constitui uma espécie de gota num imenso oceano de obras. Assim é que de certo modo a literatura brasileira é relativamente pouco conhecida na França pelo público que desconhece o português. Se pensarmos em termos de êxito de circulação, ou seja de número de traduções, vendas, reedições, chama a atenção, na história das traduções brasileiras da França, o impacto que tiveram a obra de Jorge Amado e um romance de José Mauro Vasconcelos, O meu pé de laranja lima. Esses exemplos constituíram exceções num cenário de pouco conhecimento, para além do círculo de especialistas, apesar do aumento progressivo do número de obras traduzidas.

Também podemos nos interrogar sobre outra dimensão da repercussão, que diz respeito à fortuna crítica e criativa da literatura brasileira. A esse respeito, qual é o impacto dos textos traduzidos sobre a produção cultural francesa? Creio que ele é relativamente modesto, é quase imperceptível a fecundidade desses textos junto a autores e pensadores franceses. De quais autores brasileiros podemos dizer que têm ou tiveram, na França, uma repercussão semelhante à que têm as obras de Cortazar, Octavio Paz, Umberto Eco? Talvez Lispector, que foi o primeiro nome da literatura brasileira a ter toda sua obra traduzida e que atualmente está ganhando nova tradução.

\section{Dê notícias também da literatura contemporânea brasileira: o que tem chegado a terras} francesas?

Muitos são traduzidos: Milton Hatoum, Ana Maria Machado, Conceição Evaristo, Domicio Proença Filho, Julian Fuks, Ronaldo Correia de Brito, Cristóvão Tezza, Guiomar de Grammont, Bernardo Carvalho, Adriana Lisboa... Uma longa lista, em que faltam poetas e 
contistas. O programa de apoio à tradução e residência de tradutores da Fundação Biblioteca Nacional, raríssima iniciativa pública brasileira a ter sido mantida ao longo dos anos, tem contribuído bastante para que autores contemporâneos sejam publicados.

\section{Como se dá a circulação da literatura infantil brasileira na realidade em que você atua?}

Os especialistas de literatura infantil conhecem os brasileiros que receberam o prêmio Andersen: Lygia Bonjunga Nunes, Ana Maria Machado, Roger Mello. Mas nem sempre as suas obras estão facilmente disponíveis em livrarias. Lobato nunca foi traduzido e não sei se teria sentido em traduzi-lo hoje em dia.

De uns tempos para cá, a ideia de internacionalização da literatura brasileira tem sido tema de muitos debates. Quais são os principais desafios para essa internacionalização?

No caso da internacionalização junto ao público francês, acho que o grande desafio é o de conseguir ultrapassar uma situação de verdadeiro confinamento, interessando quase somente o círculo de leitores que já se interessam pelo Brasil ou que abrem esses livros para nele buscarem um mero documento capaz de "traduzir" a realidade brasileira.

Qual é a importância de fazer circular a literatura e a cultura brasileiras no momento histórico em que vive o país?

Mais do que nunca, o diálogo entre Brasil e França pode e deve ser instaurado através da cultura e das artes. As medidas calamitosas e o discurso desastroso do governo atual vão passar. Deixarão marcas mas passarão. Já a produção cultural brasileira, ela continuará a existir. Como nunca, é fundamental que se continue a divulgar artistas e pensadores brasileiros. É uma maneira de apoiar a produção cultural e, além de tudo, um modo de lembrar que o Brasil segue sendo o Brasil, no sentido de solo de onde brotou o romance de Machado de Assis, a pintura de Adriana Varejão, a escultura de Tunga, a música de Egberto Gismonti, o cinema de Nelson Pereira dos Santos. 